\title{
Evaluating the Global Forecast System (GFS) for energy management over Minas Gerais State (Brazil) against in-situ observations
}

\author{
Rafael Arcanjo DE OLIVEIRA FILHO ${ }^{1 *}$, Vanessa Silveira BARRETO CARVALHO ${ }^{1}$ \\ and Michelle Simões REBOITA ${ }^{1}$ \\ ${ }^{1}$ Av. B.P.S., 1303. Pinheirinho, Itajubá - MG - Brazil. Institute of Natural Resources - Federal University of Itajubá. \\ *Corresponding author: rafaarcanjoflho@gmail.com
}

Received: May 29, 2020; accepted: December 7, 2020

\begin{abstract}
RESUMEN
Varias regiones de Brasil han experimentado períodos de intensa sequía en las últimas décadas. Las centrales hidroeléctricas producen la mayor parte de la energía del país y una reducción en el caudal de los embalses puede comprometer al sector energético. Por lo tanto, el gobierno brasileño ha buscado la diversificación de la producción de energía con otras fuentes renovables. La introducción de nuevas fuentes renovables, como energía eólica y solar, requiere estudios detallados de las condiciones climáticas locales, generalmente a través del análisis de datos históricos. Sin embargo, varias áreas de Brasil no tienen buena densidad de estaciones meteorológicas. En dicho contexto, este estudio tiene como objetivo evaluar la capacidad del producto de reanálisis del Sistema de Pronóstico Global (GFS) para representar el viento en el estado de Minas Gerais (MG), que produce el 79.5\% de la energía de recursos hídricos. Si bien el estudio considera una región específica, presenta una metodología que se puede replicar en regiones donde no hay datos disponibles. En la mayoría de las áreas los valores de velocidad del viento a $10 \mathrm{~m}$ de GFS fueron similares a los registrados por las estaciones meteorológicas. Los resultados a 10 y $100 \mathrm{~m}$ de altitud muestran altos valores de velocidad del viento en el norte del estado, región donde también se registran las mayores densidades de potencia $\left(\sim 150 \mathrm{~W} \mathrm{~m}^{-2}\right.$ durante invierno y primavera). En conclusión, el producto de reanálisis GFS, aunque con los sesgos aquí reportados, puede ser utilizado en regiones con datos meteorológicos insuficientes para estimar el potencial de producción de energía eólica como fuente complementaria de hidroelectricidad.
\end{abstract}

\begin{abstract}
Several regions of Brazil have experienced periods of intense drought in the last decades. Hydropower plants produce most of the country's energy and a reduction in reservoir flow can compromise the energy sector. Therefore, the Brazilian government has sought the diversification of energy production with other renewable sources. The introduction of new renewable sources, such as wind and solar, requires detailed studies of the local weather conditions usually through historical data analysis. However, several areas in Brazil lack weather stations. In this context, this study aims to assess the ability of the Global Forecast System (GFS) reanalysis product to represent wind, in the state of Minas Gerais (MG) which has $79.5 \%$ of energy production associated with water resources. Although the study considers a specific region, it presents a methodology that can be replicated in regions where data is not available. Over most areas, $10 \mathrm{~m}$ wind speed values of the GFS reanalysis were similar to those registered by weather stations. Results at 10 and $100 \mathrm{~m}$ of altitude show high wind speed values in the north of the state, a region where the highest power densities are also recorded (approximately $150 \mathrm{~W} \mathrm{~m}^{-2}$ during winter and spring). In conclusion, the GFS reanalysis product, albeit with the biases reported here, can be used in regions with scarce meteorological data to estimate the potential for wind energy production as a complementary source of hydroelectricity.
\end{abstract}

Key words: Renewable energy, Wind power density, GFS reanalysis. 


\section{Introduction}

Energy production depends on different local factors, such as climate and terrain (Tan and Zhi, 2016). The large availability of water resources in Brazil is used for human consumption, industry, agriculture, and energy production. According to the Energy Research Company (EPE, 2019), renewable resources in Brazil generated 495.290 GWh of electricity in 2018, and almost $80 \%$ by hydropower plants.

Adami et al. (2017) estimated the wind energy generated worldwide from 2006 to 2016, indicating an average growth of $23 \%$, and currently representing 3\% of the total energy generated worldwide. This growth can be associated with public policies which encourage wind power generation (Adami et al., 2017; Raimundo et al., 2018; Rego and Ribeiro, 2018). Brazil created, through Law N ${ }^{\circ} 10.438$ of April 26 of 2002, the Alternative Energy Sources Incentive Program (PROINFRA) to increase the use of alternative renewable resources to produce energy, especially encouraging wind farms, small hydroelectric power plants, and biomass sources in order to reach $10 \%$ of country's annual electricity consumption by 2022 (Brasil, 2002). In 2018, wind and solar power plants were responsible for, respectively, $9.78 \%$ and $0.70 \%$ of the total energy production (EPE, 2019).

Minas Gerais (MG) located in southeastern Brazil is the fourth largest state in territorial extension, with an area of $\sim 587000 \mathrm{~km}^{2}$, a population of $\sim 21$ million people and a Human Development Index (HDI) of 0.731 . Its main economic activities are: agriculture, livestock, industry, services, power generation, and mining (IBGE, 2018). MG is the fourth state in terms of power generation in Brazil. However, due to the high demand, the production is still insufficient, and for example in 2017, the state generated only $54.3 \%$ of its energy demand. A decrease in production in 2014 and 2015 due to an intense drought period (Coelho et al., 2016) contributed an increase on external energy dependence (3.4\% per year). Energy production in $\mathrm{MG}$ corresponds to $7.35 \%$ of the total national production from basically three sources: hydro $(79.0 \%)$, thermal (19.2\%), and solar (1.8\%). No energy is produced by wind sources in $M G$, despite the existence of a wind power plant in the city of Gouveia (Jequitinhonha Valley), but not in operation due to financial reasons (CEMIG, 2019; EPE, 2019). The large seasonal and interannual variability in rainfall rates hinders energy production and, according to the AR5 Synthesis Report from Intergovernmental Panel on Climate Change (IPCC, 2014), climate projections indicate the intensification of weather extremes, placing the hydroelectric system at risk. Due to the severe droughts during 2014 and 2015 in the southeastern region of the country, where $42.13 \%$ of the Brazilian population lives (IBGE, 2018), local governments were forced to implement energy rationing and to reduce water distribution for human consumption (Ribeiro, 2017).

Natividade et al. (2017) through the analysis of observations and projections data, identified an increase in the number of dry days in the northern region of MG; meanwhile, Reboita et al. (2018b) revealed an increase of dry consecutive days and a decrease of wet consecutive days in most MG from precipitation projections. Potential Evapotranspiration also shows positive trends directly proportional to temperature trends in MG (Salviano et al. 2016). With higher availability of moisture in the atmosphere, the number of rainfall extreme events can increase. Reboita et al. (2018b) analyzed climate projections for MG and indicated an increase of extreme events mainly in the austral summer. All these climate factors directly affect water level in reservoirs.

Towers for wind energy generation need to be at least $100 \mathrm{~m}$ tall, to avoid the drag effect of the wind at the surface. Moreover, wind intensity projections at $100 \mathrm{~m}$ using the RegCM4 regional climate model for MG (RCP8.5 scenario) showed only slight differences between the near future (2020 to 2050) and the present (1979-2005) of $\sim 0.5 \mathrm{~m} \mathrm{~s}^{-1}$ depending on the season and state region. Differences between the present and the far future, however, presented variations of around $1 \mathrm{~m} \mathrm{~s}^{-1}$ (Reboita et al., 2018a). These results may indicate that wind patterns are less vulnerable to climate change when compared with other weather variables and it could be a promising source of electricity production in the state, complementing the hydroelectric source (Reboita et al., 2018a).

The wind resource assessment and characterization of a given region needs to consider information about the availability and variability of local winds. The Wind Power (2019) highlights that minimum extreme intensity values (less than $4 \mathrm{~m} \mathrm{~s}^{-1}$ ) may not move the turbines; speeds between 13 and $25 \mathrm{~m} \mathrm{~s}^{-1}$ do not generate increases in power density; and 
maximum extremes (higher than $25 \mathrm{~m} \mathrm{~s}^{-1}$ ) can cause severe structural damage to the towers. Moreover, small variations in wind intensity generate significant variations in energy production since the power density is proportional to the cube of the wind speed (Emeksiz and Cetin, 2019).

The approval and installation of wind power projects require initial studies with at least five years of data from weather stations at 50, 70, and $100 \mathrm{~m}$ which, in general, are scarce in Brazil (Cancino-Solorzano and Xiberta-Bernat, 2009). The Wind Atlas of the MG Energy Company used the Mesomap system, complemented by data from anemometric measurement stations, to assess wind energy potential throughout the state. The Mesomap system is a set of atmospheric simulation models that consists of the Mesoscale Atmospheric Simulation System (MASS) with a horizontal resolution of $3.6 \mathrm{~km} \mathrm{x} 3.6 \mathrm{~km}$ (CEMIG, 2010). The results show wind in $\mathrm{MG}$ reaches values above $8 \mathrm{~m} \mathrm{~s}^{-1}$ during the winter and mainly in the northern region. However, in the absence of observations, the use of Numerical Weather Forecast (NWF) models can help in the decision-making process. Its results also can help to identify possible new viable sources of renewable energy and contribute to the diversification of state production. Therefore, this study aims to assess the ability of the Global Forecasting System (GFS) reanalysis product to estimate the potential for wind power generation, using the state of MG - Brazil from 2013 to 2017 as an example. The GFS model results data are available through the National Oceanic and Atmospheric Administration (NOAA, 2018) since 1980; therefore, the methodology presented in this study can be applied to other regions where observations are scarce or unavailable.

\section{Methodology}

\subsection{Data}

The GFS is a global weather forecasting model (NOAA, 2018), developed and operated by the National Centers for Environmental Prediction (NCEP), which uses the Gridpoint Statistical Interpolation (GSI) as a global analysis scheme (Rajagopal et al., 2007; Prasad et al., 2011). The GSI is included in the Global Data Assimilation and Forecasting (GDAF) system at National Centre for Medium Range Weather Forecasting (NCMRWF) and the assimilation runs are performed using the six-hour intermittent method (the system has access to a database observed four times a day), where three main interactions are carried out (between predictions and observations) and the analyses are used as initial conditions for subsequent predictions (Prasad et al., 2011; 2017). The results of the GFS analyses (meteorological term applied to indicate a model result that is not a forecast) were used with horizontal resolution of 0.5 degrees, 64 vertical levels, and six-hour frequency $(0$, 6,12 and 18 UTC). The period considered was from 2013 to 2017 for the entire state of MG. From the zonal (UGRD) and meridional (VGRD) components, the intensities $\left(\mathrm{m} \mathrm{s}^{-1}\right)$ and directions $\left({ }^{\circ}\right)$ of the wind were obtained every six hours. Daily and monthly averages were also calculated.

To verify how the GFS analyses represent the weather conditions in the state, observations at $10 \mathrm{~m}$ from twelve weather stations between 2013 and 2017 were used (Table I). These weather stations belong to the National Institute of Meteorology (INMET) and were chosen according to the mesoregions of the State of MG. These regions were defined, based on economic and social similarities, by the Brazilian Institute of Geography and Statistics (Brazilian Institute of Geography and Statistics - IBGE, 2018). For comparison, GFS data were extracted from the nearest grid points of the weather stations. Figure 1 shows the location of the stations and terrain elevation through the state. In the south, the altitude is higher, characterized by the Mantiqueira Mountains (Serra da Mantiqueira). In the north the altitude is more heterogeneous, with the Espinhaço Mountains (Serra do Espinhaço) and the São Francisco River Depression, for example (CEMIG, 2010).

\subsection{Statistical Analyses}

The evaluation of the wind speed and direction from GFS results was made through graphs and wind roses. Data obtained by weather stations were also compared with model results (at $10 \mathrm{~m}$ ). Seasonal, monthly, and diurnal variability analyses of wind speed data were also performed. The diurnal cycle variability is important, as it allows the identification of the time when the wind reaches its highest intensity in a given location; in general, efficient production of wind energy will occur when the highest wind speed is recorded. The average 6-hour and monthly wind 
Table I. List of weather stations.

\begin{tabular}{lclcc}
\hline Region & Code & Station & Latitude & Longitude \\
\hline Campo das Vertentes & A514 & São João Del Rei & $21.10^{\circ} \mathrm{S}$ & $44.25^{\circ} \mathrm{W}$ \\
Central Mineira & A538 & Curvelo & $18.74^{\circ} \mathrm{S}$ & $44.45^{\circ} \mathrm{W}$ \\
West & A524 & Formiga & $20.45^{\circ} \mathrm{S}$ & $45.45^{\circ} \mathrm{W}$ \\
Northwest & A553 & João Pinheiro & $17.78^{\circ} \mathrm{S}$ & $46.11^{\circ} \mathrm{W}$ \\
North & A506 & Montes Claros & $16.68^{\circ} \mathrm{S}$ & $43.84^{\circ} \mathrm{W}$ \\
Metropolitan Region & F501 & Belo Horizonte & $19.98^{\circ} \mathrm{S}$ & $43.95^{\circ} \mathrm{W}$ \\
South & A515 & Varginha & $21.56^{\circ} \mathrm{S}$ & $45.40^{\circ} \mathrm{W}$ \\
Triângulo Mineiro & A507 & Uberlândia & $18.91^{\circ} \mathrm{S}$ & $48.25^{\circ} \mathrm{W}$ \\
Jequitinhonha Valley & A537 & Diamantina & $18.23^{\circ} \mathrm{S}$ & $43.64^{\circ} \mathrm{W}$ \\
Zona da Mata & A518 & Juiz de Fora & $21.76^{\circ} \mathrm{S}$ & $43.36^{\circ} \mathrm{W}$ \\
Mucuri Valley & A527 & Teófilo Otoni & $17.89^{\circ} \mathrm{S}$ & $41.51^{\circ} \mathrm{W}$ \\
Doce River Valley & A511 & Timóteo & $19.56^{\circ} \mathrm{S}$ & $42.56^{\circ} \mathrm{W}$ \\
\hline
\end{tabular}

the acronym was explained in the text): Source: Adapted from INMET (2018)

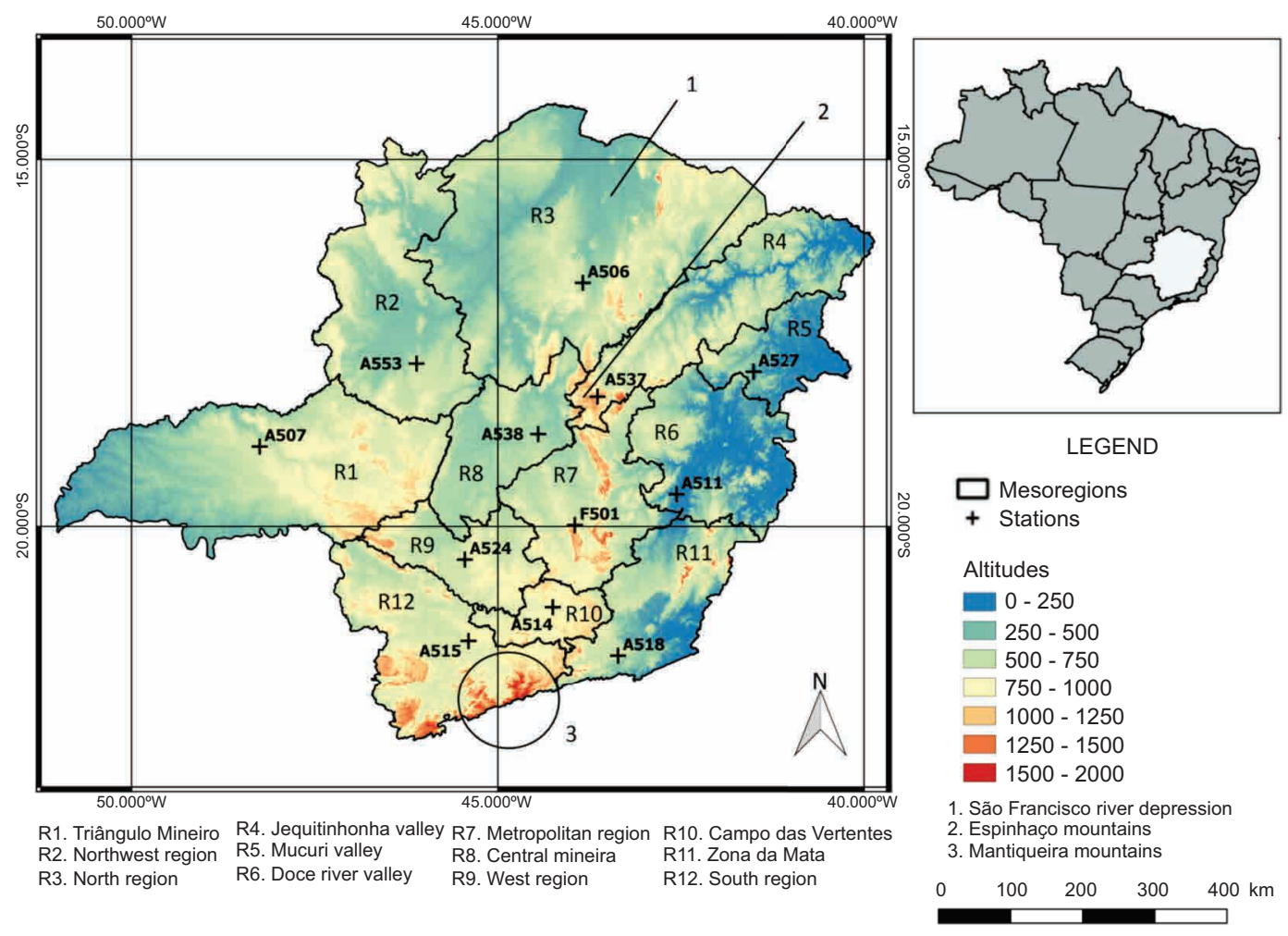

Fig 1. Location of MG state in relation to Brazil, spatial distribution of meteorological stations $(+)$ and topography (m) of MG. Different regions within the state are denoted as R1, R2, ..R12.

profiles from observational data and GFS results were also compared.

The frequency distribution of wind intensity can be represented by the Weibull distribution. This distribution has been adjusted to the GFS analysis and observational data to identify the constancy of wind intensity around an average value. Note that the Weibull distribution depends only on two parameters: the " $k$ " shape and the " $c$ " scale (Chandel et al., 2014; Wais, 2017). These parameters were obtained 
through Equations 1 and 2 respectively, where $\sigma$ is the standard deviation, $\bar{v}$ is the average velocity and the gamma function $(\Gamma)$. The parameter " $k$ " is related to the shape of the wind speed distribution (dimensionless), and it is strictly related to the standard deviation of wind speed data while the parameter " $c$ " is directly related to the average wind speed $\left(\mathrm{ms}^{-1}\right)$ (Wais, 2017; Katinas et al., 2018). The parameters of the Weibull distribution are a simple way to compare different datasets.

$$
\begin{aligned}
& k=\left(\frac{\sigma}{\bar{v}}\right)^{-1.086} \\
& c=\frac{\bar{v}}{\left[\Gamma\left(1+\frac{1}{k}\right)\right]}
\end{aligned}
$$

\subsection{Wind Power Density (WPD)}

Kalmikov (2017) indicates that seasonal mean power density (WPD) values are more advantageous than wind speed values, especially when comparing locations with asymmetric frequency characteristics, given the sensitivity of WPD to wind variations. WPD $\left(\mathrm{W} \mathrm{m}^{-2}\right)$ was calculated from the GFS using Equation 3, widely used nowadays. This methodology was also applied by Hennessey Jr. (1977), Patel (2006), Silva et al. (2016), Reboita et al. (2018a), and Emeksiz et al. (2019), and considers the air density $\left(\rho=1.225 \mathrm{~kg} \mathrm{~m}^{-3}\right)$ and the wind speed $(v)$ :

$$
W P D=c p \frac{1}{2} \rho v^{3}
$$

Calculating WPD per unit area $\left(\mathrm{W} \mathrm{m}^{-2}\right)$ and considering the maximum power coefficient $(c p)$ imposed by the Betz Law. The Betz Limit shows the maximum efficiency can be obtained from a wind turbine is $59.3 \%$, which means the ratio between the input and output of the wind turbine is one third (Manwell et al., 2009; Burton et al., 2011). Thus, $c p=0.593$.

Elliotti et al. (1991) previously used WPD = $0.955 \rho v^{3}$ to calculate tables of wind power density classification for winds measured at 10 and $50 \mathrm{~m}$. Table II is a modified version of the one presented in Elliotti et al. (1991), comparing original WPD estimates with those calculated from Eqn. 3 and including data at $100 \mathrm{~m}$.

\section{Results and Discussion}

\subsection{Wind Spatial Distribution}

Wind seasonal averages at 10 and $100 \mathrm{~m}$ are shown in Figures 2 and 3, respectively. Wind averages vary over the seasons due to intensification or weakening of atmospheric systems, mainly associated with the South Atlantic Subtropical Anticyclone (SASA), South Atlantic Convergence Zone (SACZ), and Frontal Systems (Reboita et al., 2010; Reboita et al., 2015; Reboita et al., 2019).

GFS indicates that, in general, the wind at $10 \mathrm{~m}$ (Fig. 2) has low intensity, not exceeding $2 \mathrm{~m} \mathrm{~s}^{-1}$ in

Table II - Classification of wind power density, where $\mathrm{v}$ is the wind speed $\left(\mathrm{ms}^{-1}\right)$ and WPD is the wind power density $\left(\mathrm{W} \cdot \mathrm{m}^{-2}\right.$ ). The WPD 1 correspond to values for 10 and $50 \mathrm{~m}$ calculated in the original study based on the Rayleigh distribution (Elliotti et al., 1991). WPD 2 values were calculated using Equation 3.*Values calculated for $100 \mathrm{~m}$, maintaining the calculation standard of the original publication.

\begin{tabular}{lccccccccc}
\hline \multirow{2}{*}{ Classes } & \multicolumn{3}{c}{$10 \mathrm{~m}$} & \multicolumn{9}{c}{$50 \mathrm{~m}$} & \multicolumn{3}{c}{$100 \mathrm{~m}$} \\
\cline { 2 - 9 } & $\mathrm{v}$ & WPD 1 & WPD 2 & $\mathrm{v}$ & WPD 1 & WPD 2 & $\mathrm{v}^{*}$ & WPD 1* & WPD 2* \\
\hline 1. Poor & $0-4.4$ & $0-100$ & $0-52.2$ & $0-5.6$ & $0-200$ & $0-107.6$ & $0-6.2$ & $0-280.6$ & $0-146.9$ \\
2. Marginal & $4.4-5.1$ & $100-150$ & $52.2-81.3$ & $5.6-6.4$ & $200-300$ & $107.6-160.6$ & $6.2-7.2$ & $280.6-436.9$ & $146.9-228.7$ \\
3. Moderate & $5.1-5.6$ & $150-200$ & $81.3-107.6$ & $6.4-7.0$ & $300-400$ & $160.6-210.1$ & $7.2-7.9$ & $436.9-578.4$ & $228.7-302.8$ \\
4. Good & $5.6-6.0$ & $200-250$ & $107.6-132.3$ & $7.0-7.5$ & $400-500$ & $210.1-258.4$ & $7.9-8.5$ & $578.4-711.4$ & $302.8-372.5$ \\
5. Excellent & $6.0-6.4$ & $250-300$ & $132.3-160.6$ & $7.5-8.0$ & $500-600$ & $258.4-313.6$ & $8.5-9.0$ & $711.4-863.4$ & $372.5-452.0$ \\
6. Excellent & $6.4-7.0$ & $300-400$ & $160.6-210.1$ & $8.0-8.8$ & $600-800$ & $313.6-417.4$ & $8.0-9.9$ & $863.4-1129.7$ & $452.0-591.5$ \\
7. Excellent & $>7.0$ & $>400$ & $>210.1$ & $>8.8$ & $>800$ & $>417.4$ & $>9.9$ & $>1129.7$ & $>591.5$ \\
\hline
\end{tabular}



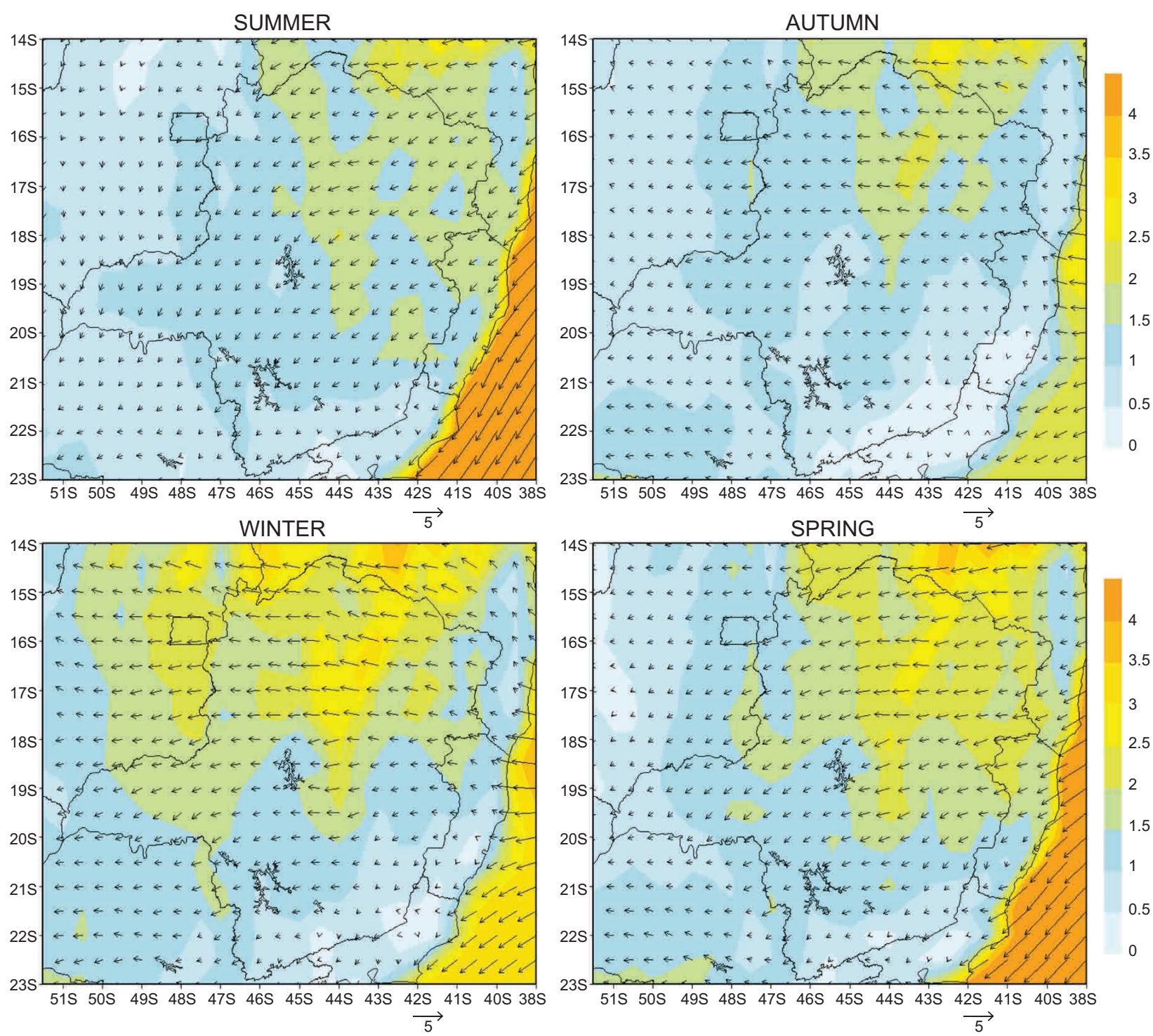

Fig 2. Wind seasonal average at $10 \mathrm{~m}$ from 2013 to 2017 . Intensity $\left(\mathrm{ms}^{-1}\right)$ is shaded and vectors indicate wind direction $\left(^{\circ}\right)$.

the south and $3.5 \mathrm{~m} \mathrm{~s}^{-1}$ upstate. However, the wind speed at $100 \mathrm{~m}$ (Fig. 3) shows higher values due to surface roughness which tends to decrease with height. The northern portion of the State shows wind speed average at $10 \mathrm{~m}$ between 1 and $2.5 \mathrm{~m} \mathrm{~s}^{-1}$ during austral summer and autumn; at $100 \mathrm{~m}$, average values between 3.5 and $4.5 \mathrm{~m} \mathrm{~s}^{-1}$ were found, respectively. During winter and spring, wind-speed values increase from 2.5 to $3.5 \mathrm{~m} \mathrm{~s}^{-1}$ (at $10 \mathrm{~m}$ ) and from 4 to $6 \mathrm{~m} \mathrm{~s}^{-1}$ (at $100 \mathrm{~m}$ ). A similar pattern is seen throughout the state. The wind speed at $100 \mathrm{~m}$ is equal to the minimum threshold for energy generation during winter and spring (dry season), which is $4 \mathrm{~m} \mathrm{~s}^{-1}$ (for small electric wind turbines) and wind turbines on a scale of public utility and $6 \mathrm{~m} \mathrm{~s}^{-1}$ (wind farms on larger scales), according to Culture Change (2017) and The Wind Power (2019). The North (R3, see map in Fig. 1) and Jequitinhonha Valley (R4) regions have the highest wind intensities, agreeing with CEMIG (2010). Higher wind speed values during winter and spring indicates a possible anti-correlation between wind and precipitation which presents minimum values in these seasons (Silva and Reboita, 2013; Reboita et al., 2015; Reboita et al., 2017; Reis et al. 

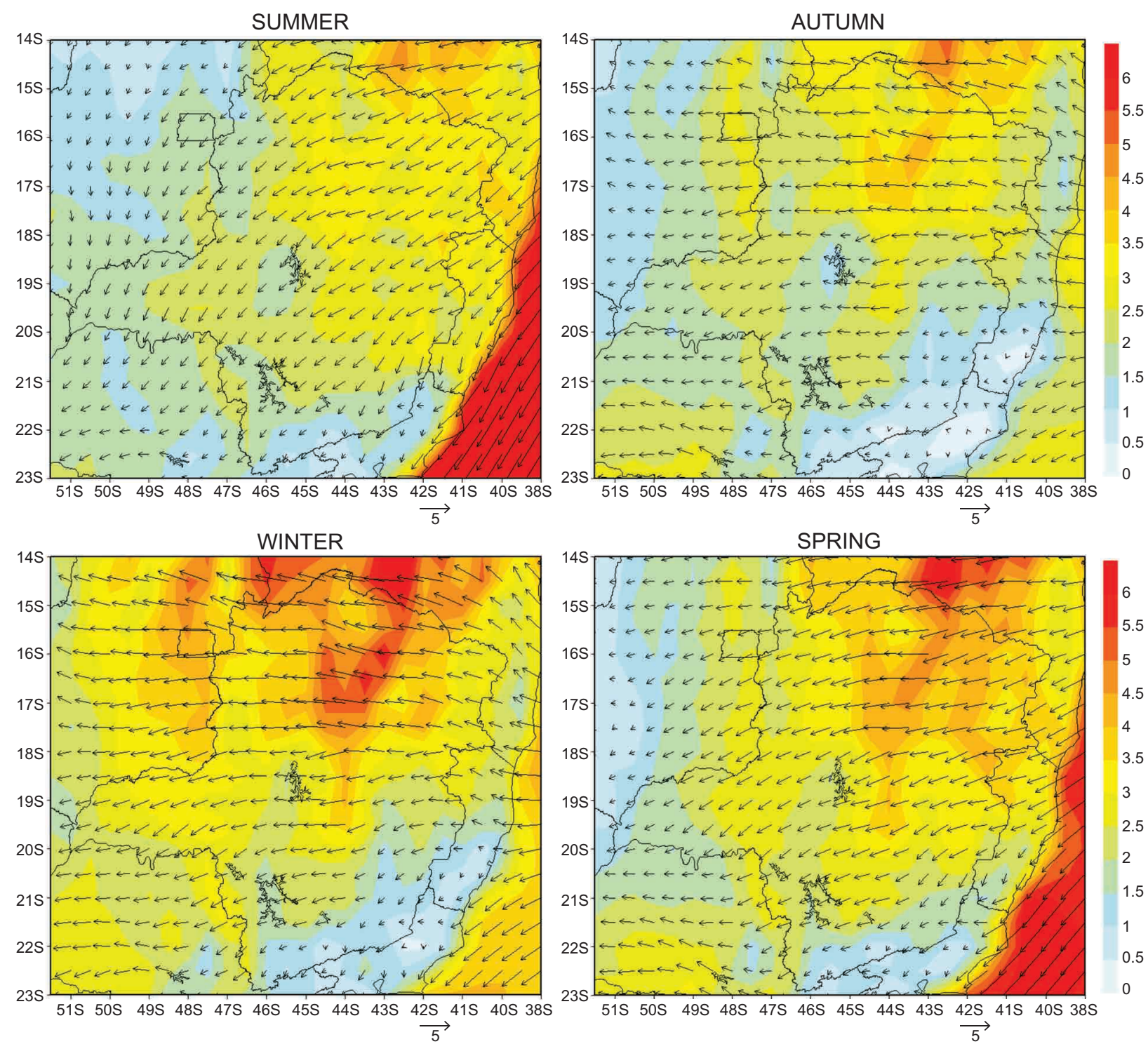

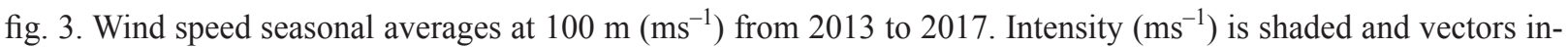
dicate wind direction $\left({ }^{\circ}\right)$

2018) and reinforces a positive factor for the expansion of wind power in the state energy matrix. Wind farms would have greater production in months with low operation of the hydroelectric power plants and thus, energy production would be complementary between the two sources.

In agreement with ERA-Interim reanalysis data and RegCM4 model results by Reboita et al. (2018a), wind density values show significant differences between northern (R3) and southern (R12) regions of MG and higher wind speed values during winter and springtime. However, ERA-Interim data presented a higher contrast between those regions; while the northern region showed wind intensity lower than $6 \mathrm{~m} \mathrm{~s}^{-1}$, the southern region presented values lower than $3 \mathrm{~m} \mathrm{~s}^{-1}$, matching those of the GFS analysis.

Another important factor is that the average wind speed is less than the maximum limit, favouring eolic energy generation throughout the day and seasons, minimizing possible structural problems. Results in Figure 4 do not differ significantly from those reported by Paula et al. (2017): wind speeds varying 

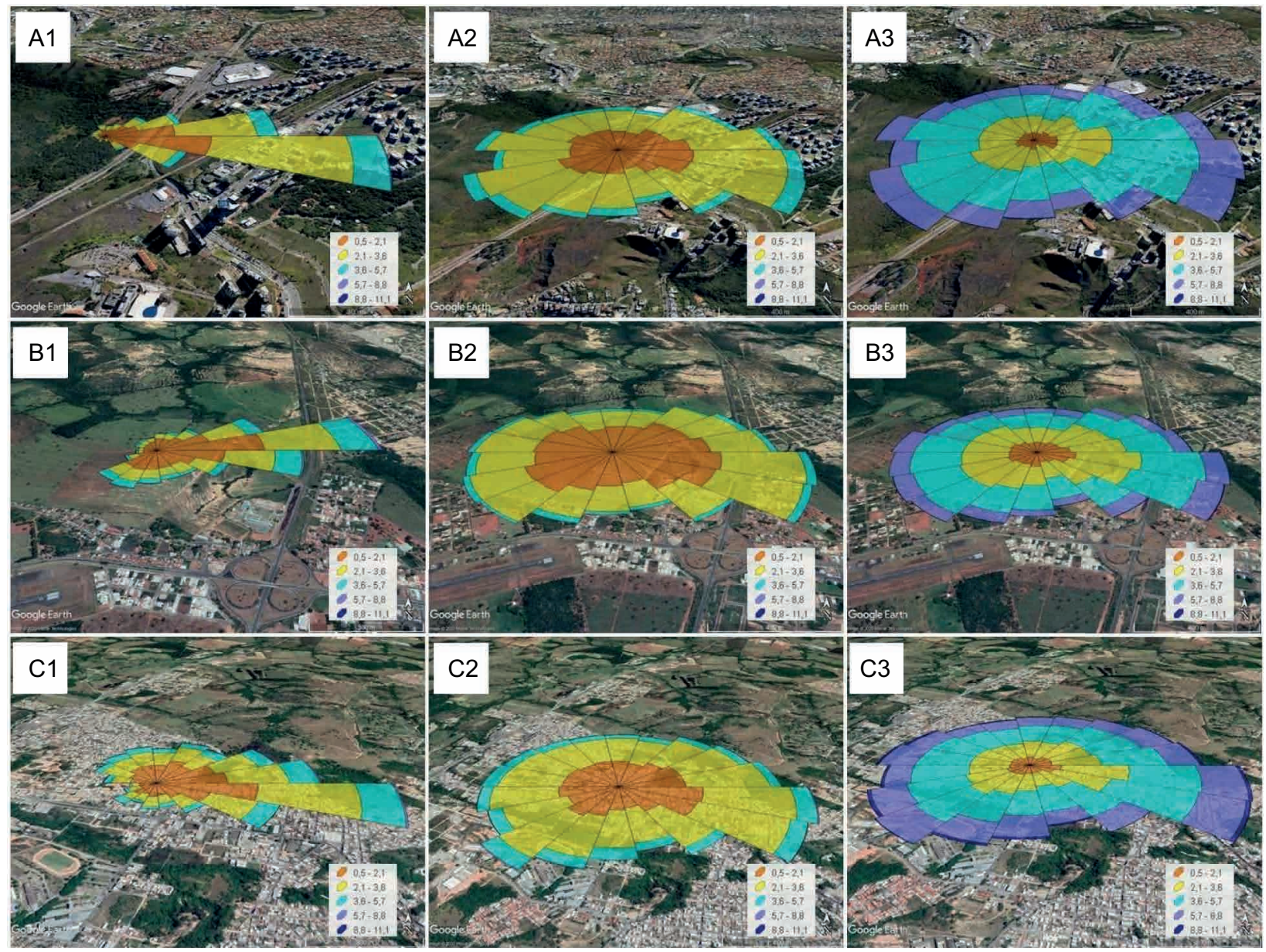

Fig. 4. Wind roses determined for the period 2013-2017 in stations: (A) Belo Horizonte, (B) Curvelo and (C) Formiga, representing: (1) observed data, (2) GFS data $(10 \mathrm{~m})$ and (3) GFS data $(100 \mathrm{~m})$. The legend is in $\mathrm{ms}^{-1}$.

from 0.8 to $5.5 \mathrm{~m} \mathrm{~s}^{-1}$, more intense in winter and in northern MG. It is worth mentioning that Paula et al. (2017) used only data from meteorological stations, and, in addition, authors performed vertical extrapolation of wind speed data to estimate values at $100 \mathrm{~m}$.

The wind direction pattern at $10 \mathrm{~m}$ and $100 \mathrm{~m}$ is mainly influenced by SASA, which plays an important role in the climate of South America. Moreover, as reported by Reboita et al. (2019), the SASA area expands to south and west in climate projections compared to its current climate position. This expansion of SASA may affect weather conditions, modifying the frequency of dry periods, and directly impacting the energy sector in southeastern Brazil. The SASA gains strength in winter and extends to the western Atlantic Ocean, hampering convective movements and cold fronts in southeastern Brazil and, consequently, reducing precipitation rates (Reboita et al., 2015; Reboita et al., 2017). Therefore, there is a possible complementarity between wind and hydroelectric power plants mainly during the winter (dry season) when hydroelectric power plants operate at low capacity.

\subsection{Analysis of predominant wind direction}

Wind direction from GFS results at $10 \mathrm{~m}$ was compared with observed wind direction data at twelve sites. Wind roses are presented for the predominant wind direction from GFS at $100 \mathrm{~m}$. Emeksiz et al. (2019) indicate the wind direction analysis can provide information to support the decision of where to install the wind turbines in order to maximize its 
efficiency. Table III shows that observational data at $10 \mathrm{~m}$ from stations presented variable directions. In contrast, the GFS data at both 10 and $100 \mathrm{~m}$, presented predominant northeast-southeast direction, while showing differences in wind speed, and not satisfactorily simulating the observed direction at $10 \mathrm{~m}$.

Table III. Predominant wind direction.

\begin{tabular}{lccc}
\hline Station & $\begin{array}{c}\text { Observed } \\
(10 \mathrm{~m})\end{array}$ & $\begin{array}{c}\text { Simulated } \\
(10 \mathrm{~m})\end{array}$ & $\begin{array}{c}\text { Simulated } \\
(100 \mathrm{~m})\end{array}$ \\
\hline Belo Horizonte & NE - SE & NE - SE & NE - SE \\
Curvelo & NE - SE & NE - SE & NE - SE \\
Diamantina & E - S & NE - SE & NE - SE \\
Formiga & NE - SE & NE - SE & NE - SE \\
Juiz de Fora & N - E & NE - SE & NE - SE \\
João Pinheiro & E - S & NE - SE & NE - SE \\
Montes Claros & N - E & NE - SE & NE - SE \\
São João Del Rei & E - S & NE - SE & NE - SE \\
Timóteo & NW - NE & NE - SE & NE - SE \\
Teófilo Otoni & NE - E & NE - SE & NE - SE \\
Uberlândia & N - E & NE - SE & NE - SE \\
Varginha & E - S & NE - SE & NE - SE \\
\hline
\end{tabular}

As an example, Figure 4 shows that Belo Horizonte (A), Curvelo (B) and Formiga (C) stations have a similar predominant wind direction at 10 and $100 \mathrm{~m}$. In contrast, wind direction from GFS are more homogenously distributed. In general, the wind turbines would be better positioned in the NE-SE direction, where they would experience the highest frequency of winds.

Moreover, Figure 4 indicates that wind direction patterns from GFS do not show significant differences between 10 and $100 \mathrm{~m}$. This absence of changes in the wind direction with height over cities (most of the stations analyzed are located in or close to urban centers) suggests little or no influence of urbanization. However, it is well known that urbanization increases energy loss at the surface, affecting both the intensity and the prevailing wind direction. Large urban centers, which expand as population grows, undergo processes that involve changes in land use and occupancy which, in turn, modify surface roughness conditions. GFS is unable to represent terrain conditions adequately well in the interpolation process of wind direction in these regions.

\subsection{Wind variability patterns}

In terms of seasonal variability, wind speed averages in MG are lower during austral summer and fall, coinciding with higher rainfall rates which guarantee that hydroelectric plants can operate at maximum efficiency. Wind speed averages are higher between July and October (austral winter) reinforcing potential complementarity between higher wind and lower precipitation. Thus, during the dry season, stronger winds can help meet the state's energy demand. At $100 \mathrm{~m}$, cities as Uberlândia, Montes Claros, and Teófilo Otoni (located in the Triângulo Mineiro (R1), North region (R3), and Mucuri Valley (R5), respectively) presented wind speed averages close to $6 \mathrm{~m} \mathrm{~s}^{-1}$. Observations and results from GFS at $10 \mathrm{~m}$ show values between 1.5 and $3 \mathrm{~m} \mathrm{~s}^{-1}$. The lowest wind speed averages were registered between February and May.

The comparison between observed and GFS profiles showed similar patterns in most sites (Fig. 5). Best results were found for Belo Horizonte, São João del Rei and Varginha (municipalities where the stations are located in areas with few obstacles, in general, with undergrowth or agricultural plantations), while greater differences can be observed in Diamantina, Montes Claros and Juiz de Fora where stations are located in areas with larger obstacles (such as high rocks in the case of Diamantina) or residential areas (in Montes Claros and Juiz de Fora). In general, the GFS model overestimated values at $10 \mathrm{~m}$ when compared to the observations, except in Diamantina, Juiz de Fora and São João Del Rei (also shown by the percentage changes).

As for diurnal wind speed variability, at $10 \mathrm{~m}$ the highest speed was recorded at $12 \mathrm{~h}$ and the lowest between $0 \mathrm{~h}$ and $6 \mathrm{~h}$, in agreement with the diurnal cycle of the Earth's surface temperature. At 100 m, the highest speed occurred between $0 \mathrm{~h}$ and $6 \mathrm{~h}$ (night and dawn) and decreased throughout the day. Observed and GFS profiles show similar patterns at most sites (Fig. 6). The GFS model also overestimated values at $10 \mathrm{~m}$ when compared to the observed values, except in Diamantina and Juiz de Fora.

\subsection{Weibull Distribution}

Statistics are used in wind studies to represent wind variability and evaluate its evolution, with respect to average values and the probability of occurrence 

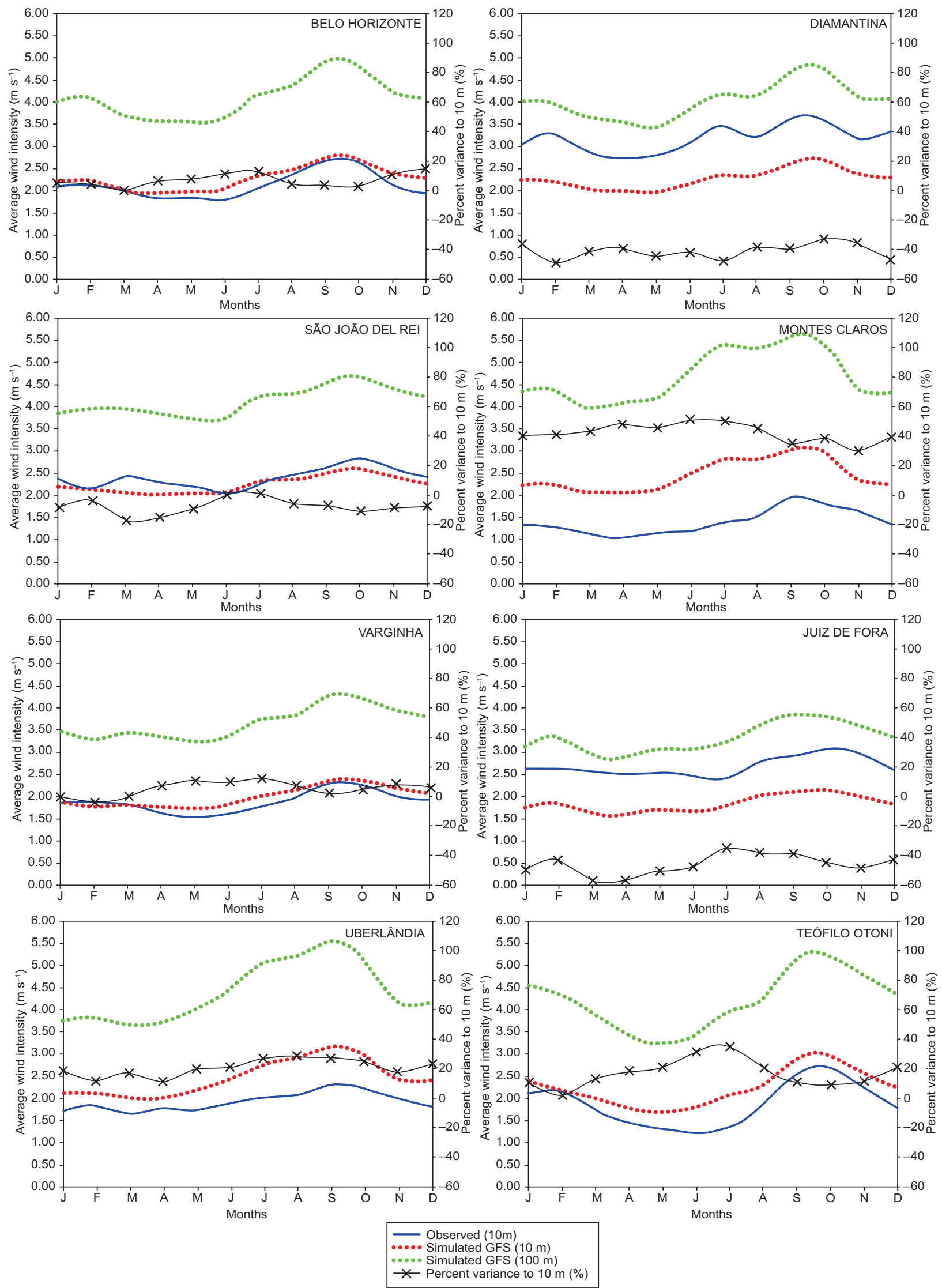

Fig. 5. Average monthly wind profile $\left(\mathrm{ms}^{-1}\right)$ observed at 8 selected sites (at $10 \mathrm{~m}$, blue line) compared with derived GFS values at $10 \mathrm{~m}$ (red dots) and at $100 \mathrm{~m}$ (green dots). The black line corresponds to the variance of the observed wind at $10 \mathrm{~m}$. 

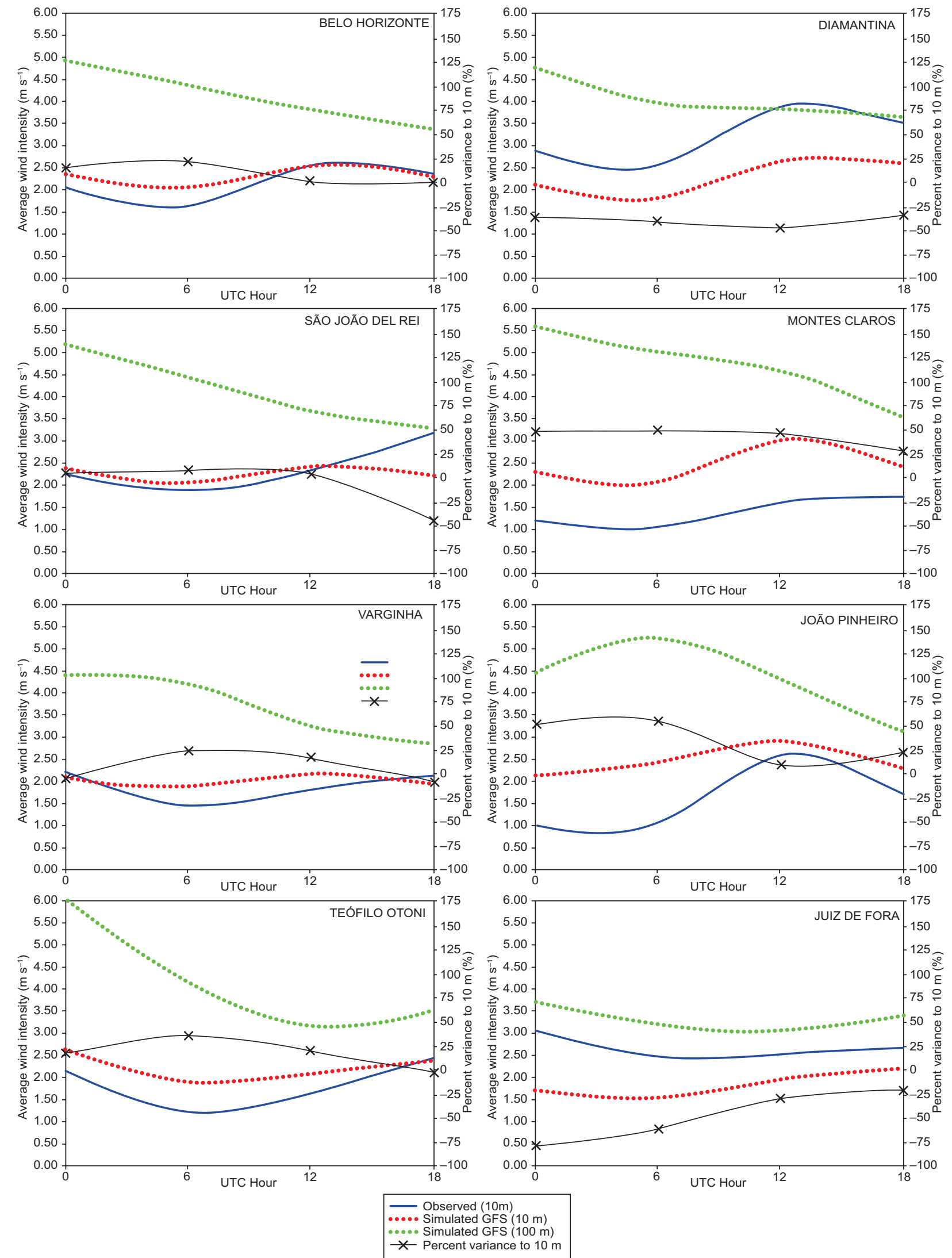

Fig. 6. Diurnal average wind profile $\left(\mathrm{ms}^{-1}\right)$ observed at 8 selected sites (at $10 \mathrm{~m}$, blue line) compared with derived GFS values at $10 \mathrm{~m}$ (red dots) and at $100 \mathrm{~m}$ (green dots). The black line corresponds to the variance of the observed wind at $10 \mathrm{~m}$. 
of extreme values, and facilitate the comparison between data sets. When the Weibull shape parameter $k$ presents high values, it indicates little variability of the wind speed around an average value, whereas the parameter $\mathrm{c}$ indicates the average value of the data. For observations at $10 \mathrm{~m}$ at all sites, $k$ values ranged between 1 and 2.16. The values of $c$ presented greater variability, as can be seen in Table IV. According to Patel (2006), when $k$ is equal or close to 1 the Weibull distribution approaches an exponential distribution, as in the case of Montes Claros (top-right panel in Fig. 8, blue line), and it indicates that most days registered calm or very weak winds. When $k$ values equal to or close to 2 (Rayleigh distribution), such as in Belo Horizonte, Diamantina, Juiz de Fora and Uberlândia, present standard distributions of wind speeds (found in most places), and in these cases most days have speeds below the average speed.

All observational datasets showed positive asymmetries, where the modal value $<$ median of the values $<$ average speed value (Pishgar-Komleh et al., 2015). Similar calculations with the GFS datasets at $10 \mathrm{~m}$ and $100 \mathrm{~m}$, result in values of $k$ between 2 and 3 (Fig. 7 and 8). Also according to Patel (2006), distributions with $k=3$ (as in Diamantina and Belo Horizonte) are similar to a normal distribution, where the number of strong winds is equal to the number of light winds (symmetric with respect to the mean). The parameter $c$, in general, was close to $3 \mathrm{~ms}^{-1}(10 \mathrm{~m})$ and $4 \mathrm{~ms}^{-1}(100 \mathrm{~m})$. Analyses carried out by Ramos et al. (2018) show distribution patterns as positive examples for eolic energy generation, as they detect only minor problems with the change of the wind (winds with less variability).

Results from observations and GFS show that the frequency of occurrence of extreme events greater than $8 \mathrm{~ms}^{-1}$ is less than $1 \%$. The analysis show that the winds have acceptable annual values of $k$ but are lower than those found in regions with high wind potential, such as the Brazilian Northeast (with $k$ values equal to or greater than 6) (CRESESB, 2001).

An accurate and reliable assessment of wind resources plays an important role in the effective use of wind energy (Shamshirband et al., 2016). Given the variety of studies carried out that confirm the efficiency of the Weibull distribution (Shoaib et al., 2017; Katinas et al., 2018; Souza et al., 2019) in wind studies, it can be concluded that the results presented show that wind intensity data, provide relevant general information on wind variability.

\subsection{Wind Power Density (WPD)}

Values of WPD depend on the wind turbine model with different power coefficients $(c p)$, as expressed in Eqn. 3. Figure 9 presents the seasonal average of WPD at $100 \mathrm{~m}$, considering the air density equal to $1,225 \mathrm{~kg} \mathrm{~m}^{-3}$. The left column in Fig. 9 disregards the maximum power conversion estimated by the Betz Law, which shows maximum yield from a wind turbine to be 59.3\% (Manwell et al., 2009). WPD

Table IV. Parameter values $k$ (distribution format, Eqn. 1) and $c$ (average speed, Eqn. 2).

\begin{tabular}{lcccccc}
\hline \multirow{2}{*}{ Station } & \multicolumn{2}{c}{ Observed $(10 \mathrm{~m})$} & \multicolumn{2}{c}{ Simulated $(10 \mathrm{~m})$} & \multicolumn{2}{c}{ Simulated $(100 \mathrm{~m})$} \\
\cline { 2 - 7 } & $\mathrm{k}$ & $\mathrm{c}\left(\mathrm{m} \mathrm{s}^{-1}\right)$ & $\mathrm{k}$ & $\mathrm{c}\left(\mathrm{m} \mathrm{s}^{-1}\right)$ & $\mathrm{k}$ & $\mathrm{c}\left(\mathrm{m} \mathrm{s}^{-1}\right)$ \\
\hline Belo Horizonte & 2.05 & 2.42 & 2.86 & 2.57 & 2.59 & 4.62 \\
Curvelo & 1.44 & 2.15 & 2.42 & 2.21 & 2.16 & 3.98 \\
Diamantina & 2.16 & 3.67 & 2.73 & 2.59 & 2.79 & 4.57 \\
Formiga & 1.50 & 2.25 & 2.52 & 2.58 & 2.24 & 4.62 \\
João Pinheiro & 1.53 & 2.87 & 2.67 & 2.78 & 2.34 & 4.86 \\
Juiz de Fora & 2.08 & 3.18 & 2.31 & 2.09 & 2.29 & 3.77 \\
Montes Claros & 1.39 & 1.73 & 2.58 & 2.78 & 2.64 & 5.30 \\
S. João Del Rei & 1.65 & 2.74 & 2.57 & 2.56 & 2.29 & 4.65 \\
Teófilo Otoni & 1.54 & 2.20 & 2.81 & 2.53 & 2.39 & 4.72 \\
Timóteo & 1.70 & 1.37 & 2.50 & 1.94 & 2.31 & 3.54 \\
Uberlândia & 1.90 & 2.24 & 2.22 & 2.78 & 2.27 & 4.97 \\
Varginha & 1.81 & 2.22 & 2.39 & 2.26 & 2.09 & 4.10 \\
\hline
\end{tabular}



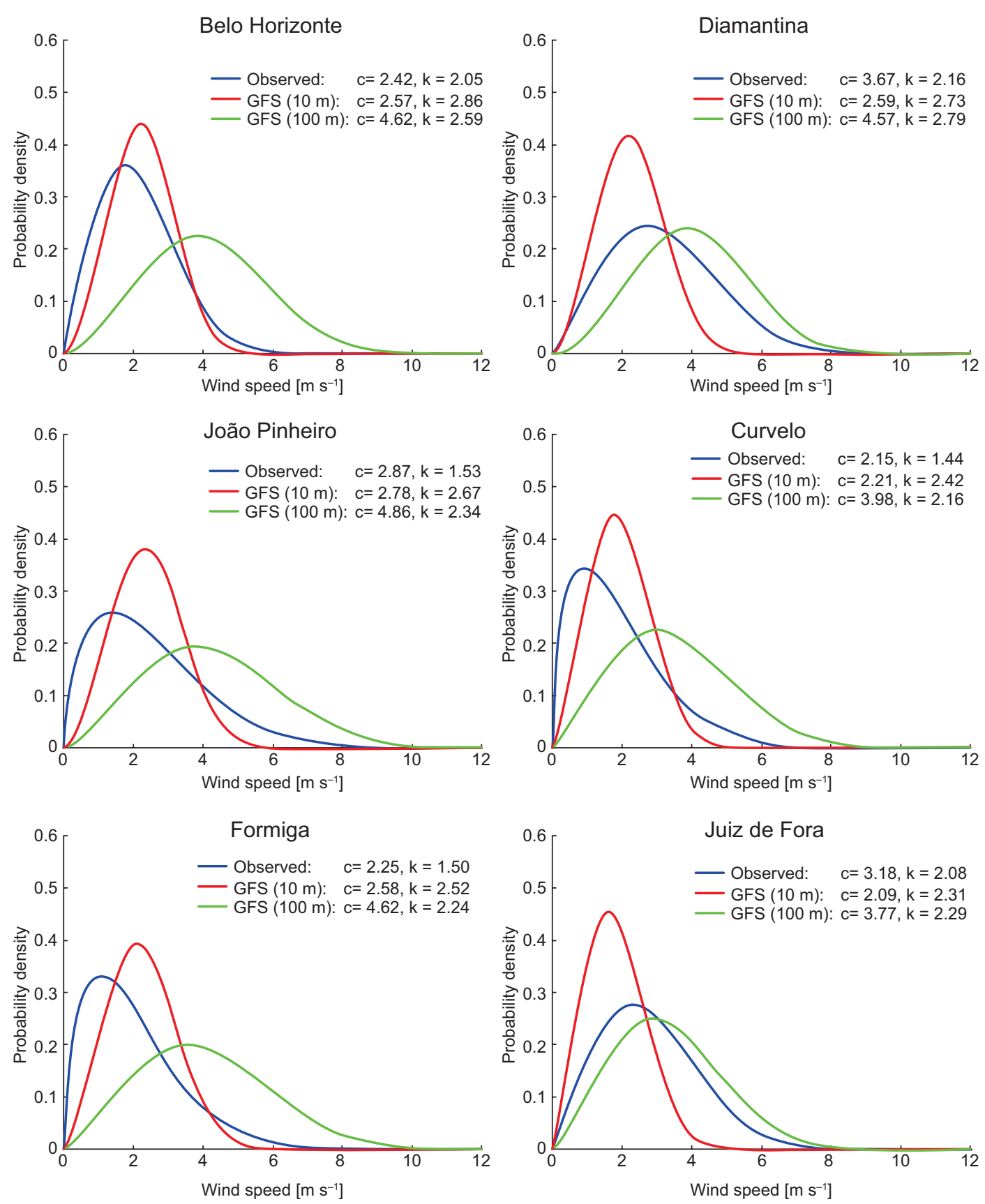

Fig. 7. Weibull distributions calculated for observed wind speed at $10 \mathrm{~m}$ (blue line) at selected 6 sites for the period (2013 - 2017) and GFS values at 10m (red line) and 100m (green line).

results show lowest values during summer and fall, below $70 \mathrm{~W} \mathrm{~m}^{-2}$ with higher values in the north and lower values in the south of MG. During winter and spring values are higher, reaching $150 \mathrm{Wm}^{-2}$ in the north region. The right column (Fig. 9) shows
WPD seasonal average at $100 \mathrm{~m}$, considering the maximum power conversion estimated by the Betz Law, resulting in an approximate $60 \%$ reduction compared to the right column. As $c p$ values depend on the wind turbine chosen, such reduction is variable, 

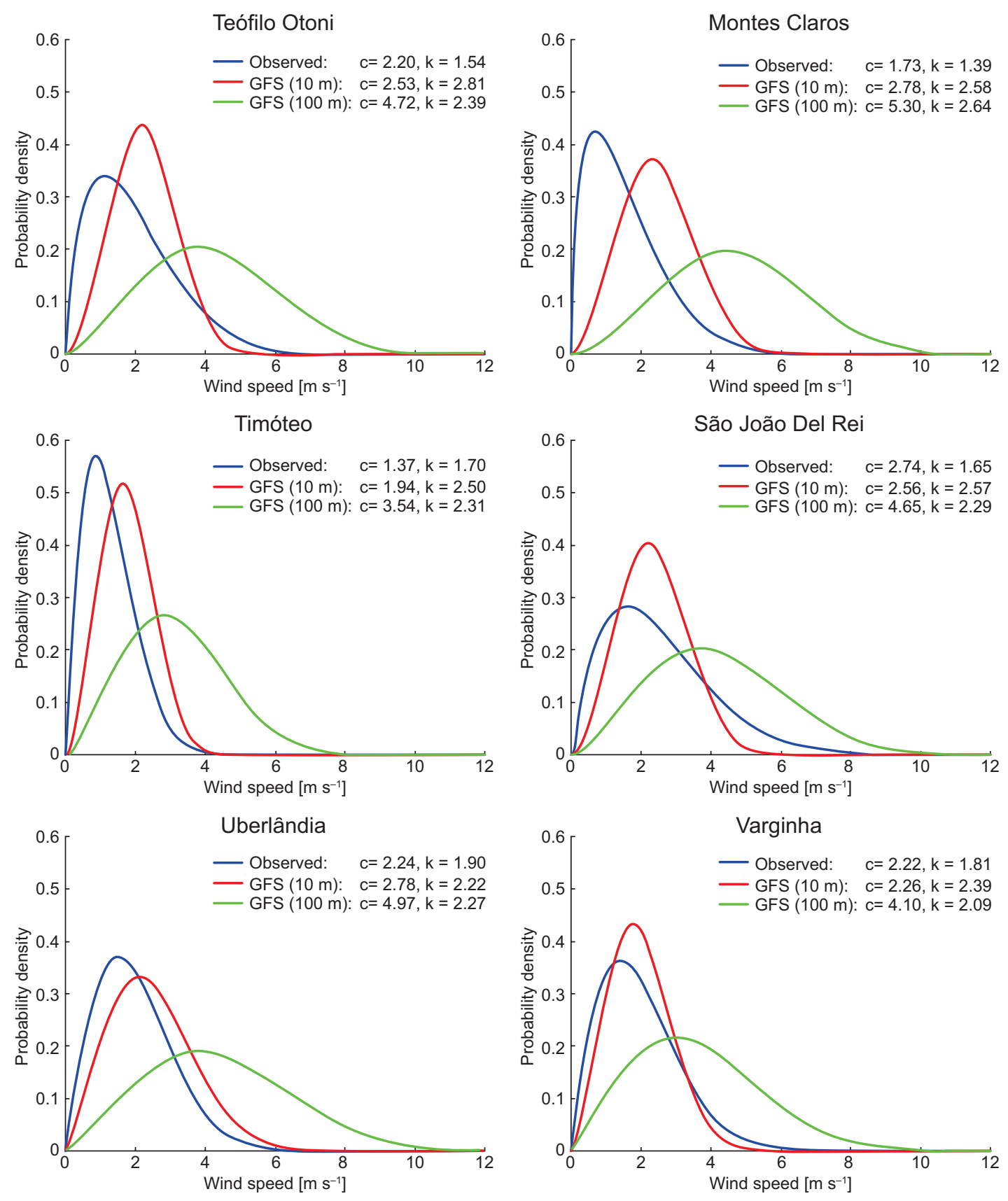

Fig. 8. Same as Figure 7 for the remaining 6 sites.

and it should be taken into account in the calculations as it influences the relationship between wind speed and generated power density.

WPD results have a high sensitivity to wind speed; therefore, its values are higher when wind speed values are higher. Regions with wind speed above $4.5 \mathrm{~ms}^{-1}$ at $100 \mathrm{~m}$ have higher wind energy generation potential.
However, the values are low when compared to results for the Northeast region of Brazil. Ramos et al. (2018) found sites in the Northeast (Alagoas State) during the dry season with WPD values around $700 \mathrm{~W} \mathrm{~m}^{-2}$, and even during the rainy season, 400 $\mathrm{Wm}^{-2}$. However, it is important to highlight that the Northeast has wind speeds higher than $8 \mathrm{~ms}^{-1}$, 


\section{SUMMER}
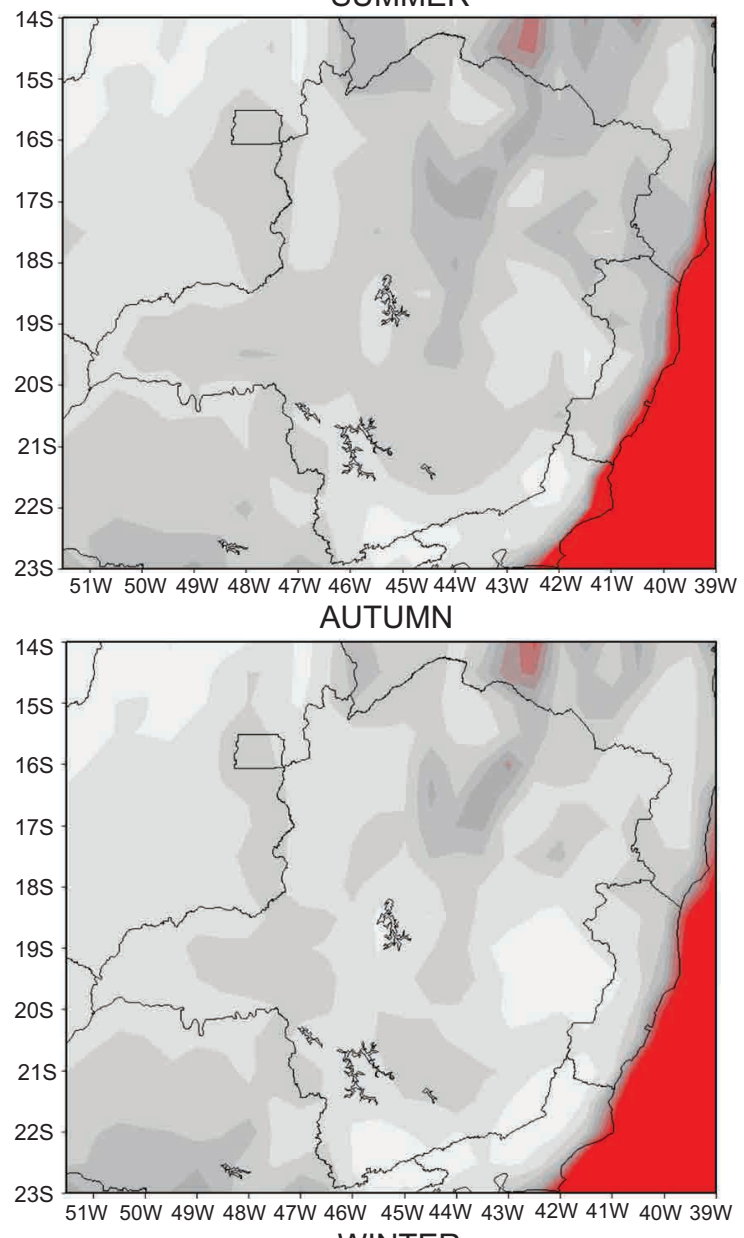

WINTER

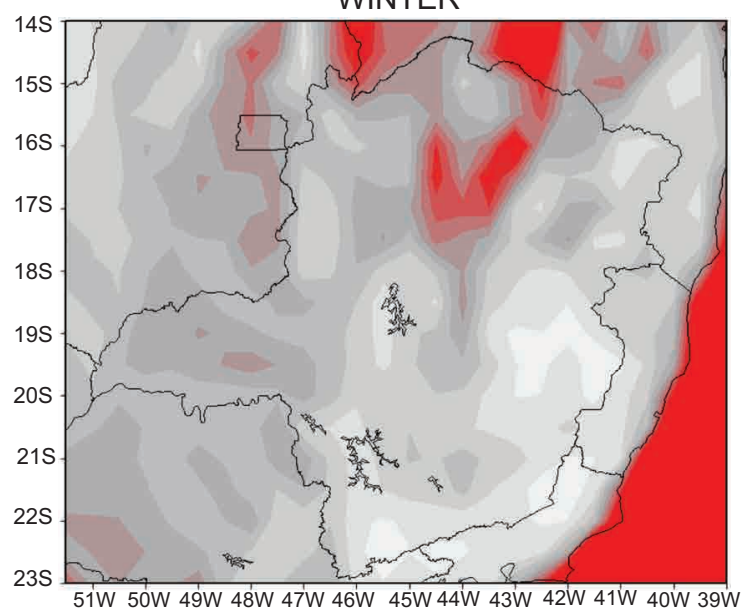

SUMMER
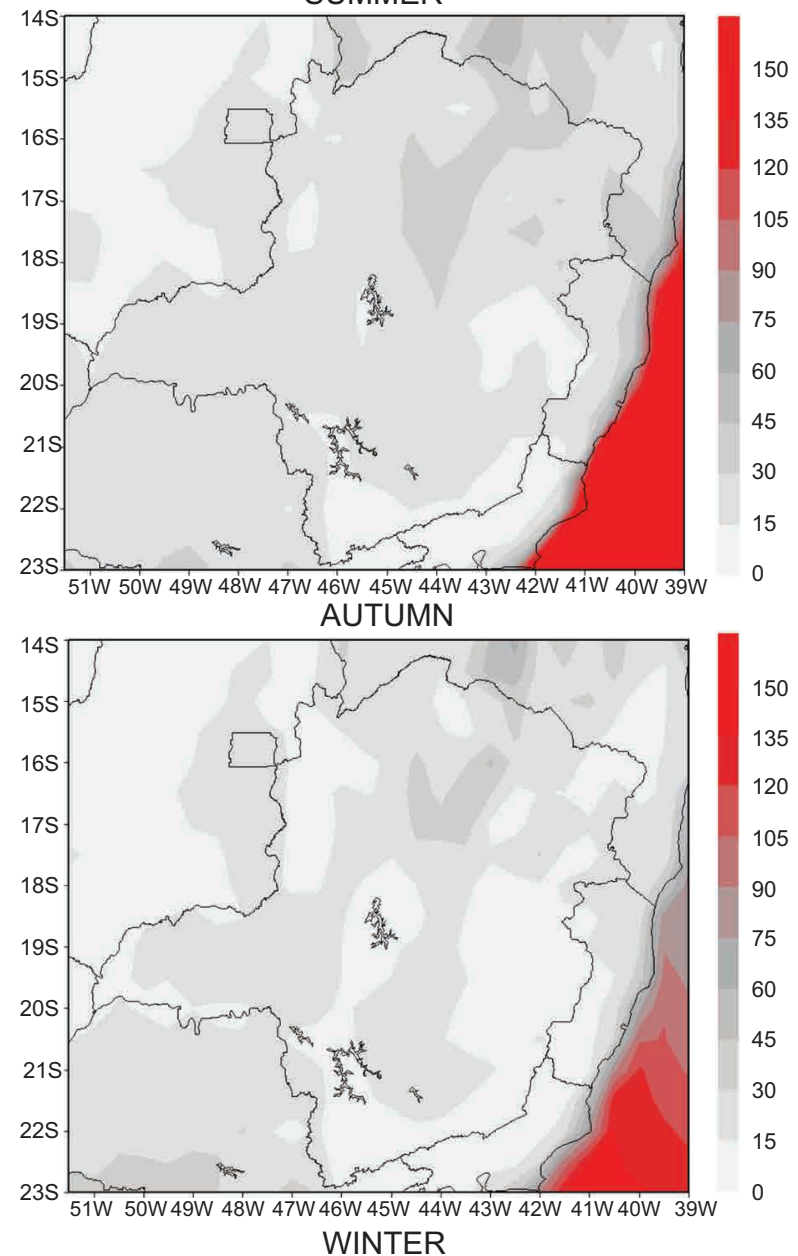

WINTER

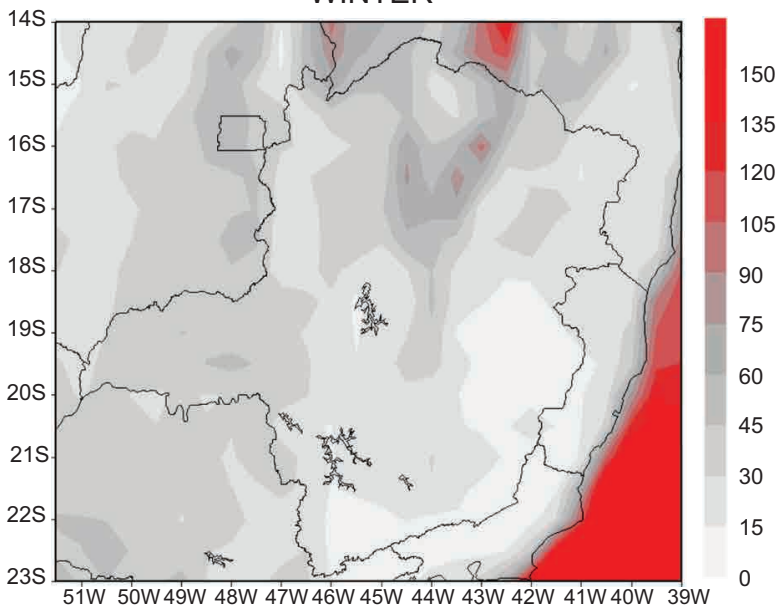

Fig. 9. WPD ( $\mathrm{Wm}^{-2}$ ) at $100 \mathrm{~m}$, from 2013 to 2017. Left column: WPD without considering cp. Right column: WPD considering the maximum $c p$ value (59.3\%) of the Betz Limit (Manwell et al., 2009). 

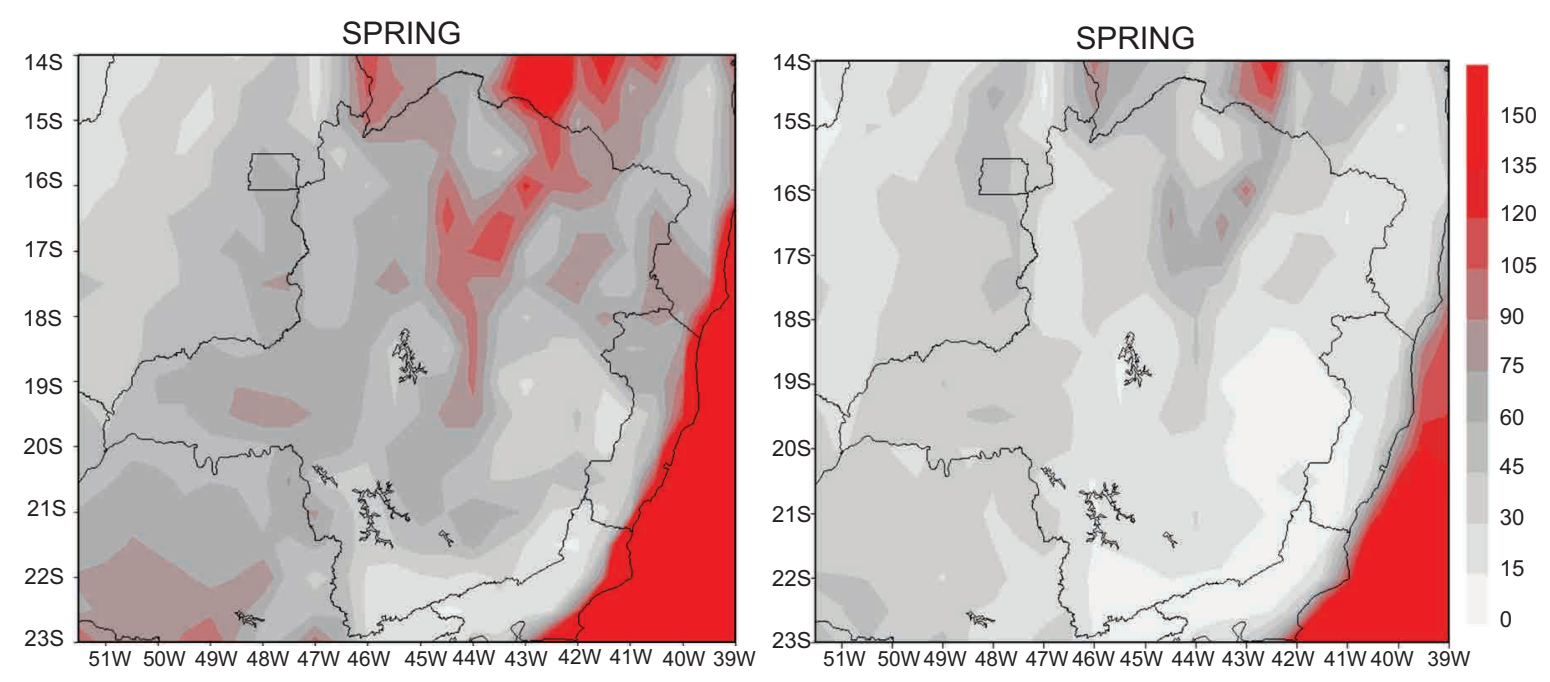

Fig. 9. WPD ( $\mathrm{Wm}^{-2}$ ) at $100 \mathrm{~m}$, from 2013 to 2017. Left column: WPD without considering cp. Right column: WPD considering the maximum $c p$ value (59.3\%) of the Betz Limit (Manwell et al., 2009).

besides high $\mathrm{k}$ values. Other regions with high WPD are located south of Bahia (Northeast region) where several wind farms already operate.

In terms of areas in the State of MG with the highest wind potential, the results confirm areas highlighted by ANEEL (2003) and CEMIG (2010), but with lower wind intensity and WPD values. However, it is important to highlight that the study conducted by CEMIG (2010) used atmospheric modeling at a higher resolution $(3.6 \mathrm{~km} \times 3.6 \mathrm{~km})$ than the GFS data. Thus, considering a spatial scale of $50 \mathrm{~km}$ adapted in this work, one can classify the wind potential of MG in Class 1 (Table II).

\section{Conclusions}

The results of the GFS analysis compared with observational data show the seasonal and spatial distribution of the wind potential of the State of MG. Both at $10 \mathrm{~m}$ and $100 \mathrm{~m}$, the lowest wind intensity was recorded during summer and autumn, and the highest during winter and spring (reaching $4 \mathrm{~m} \mathrm{~s}^{-1}$ at $10 \mathrm{~m}$ and $6 \mathrm{~m} \mathrm{~s}^{-1}$ at $100 \mathrm{~m}$ ). The interaction between the wind and the surface influenced the speed values (being greater than $100 \mathrm{~m}$ ). The average hourly wind profile indicates greater intensities of the wind at 12 UTC (at $10 \mathrm{~m}$ ) and during the night and dawn (at $100 \mathrm{~m}$ ). The spatial distribution analysis shows higher wind speed in the Northern Region of MG. In comparison with the observed wind speed data, in general, the GFS model presents similar patterns to those observed, overestimating values in most sites, except in Diamantina and Juiz de Fora. As for the predominant wind direction, there is a greater discrepancy between observed and GFS results; in addition, the model creates a similar pattern of data at 10 and $100 \mathrm{~m}$, suggesting that the GFS does not represent well the surface conditions.

Analysis in terms of Weibull distributions showed that most of the sites had a $k$ parameter between 2 and 3 , indicating that, most of the time, the recorded speeds are below average values. The parameter $c$ showed a greater variability with values close to $3 \mathrm{~m} \mathrm{~s}^{-1}$ (at $10 \mathrm{~m}$ ) and $4 \mathrm{~ms}^{-1}$ (at $100 \mathrm{~m}$ ). In addition, the frequency of occurrence of extreme events greater than $8 \mathrm{~ms}^{-1}$ was less than $1 \%$. As for the WPD at $100 \mathrm{~m}$, values are higher during winter and spring, reaching a seasonal average value equal to $150 \mathrm{Wm}^{-2}$. In this sense, it can be concluded that the North region of MG can be characterized as in Class 1, presenting low potential and reduced use for electricity generation. However, more specific studies with higher spatial resolution data are necessary in order to assess the areas of hotspots and to verify the economic, social and environmental feasibility of implementation of wind farms. 
Estimates of regions appropriate for the installation of wind energy projects require observational data at least at 2 vertical levels. Despite of the reported limitation of the GFS reanalysis product in this study, the methodology applied here can be recommended for locations with limited or no observational data. The GFS output may need to be modified to take into account local terrain features that affect both wind speed and direction, such as in urban areas. In summary, usage of output from atmospheric models (e.g. GFS) and the methodology applied in this study can provide accurate information for the decision-making process.

\section{Acknowledgments}

This research was carried out with the support of the Institute of Natural Resources of the Federal University of Itajubá and financed by the Coordination for the Improvement of Higher Education Personnel (Capes) - Financing Code 001. The authors would like to thank the National Oceanic and Atmospheric Administration (NOAA) for the availability of the Global Forecast System (GFS) model and the INMET for providing the station data used. The third author also thanks CNPq and FAPEMIG for financial support.

\section{References}

Adami VS, Antunes Júnior JAV, Sellitto MA. 2017. Regional industrial policy in the wind energy sector: The case of the State of Rio Grande do Sul, Brazil. Energy Policy 111: 18-27. https://doi.org/10.1016/j. enpol.2017.08.050

ANEEL. 2003. Banco de Informações de Geração BIG. Available at http://bit.ly/39LK90S (accessed 2020 January 29)

BRASIL. Lei ${ }^{\circ} 10.438$, de 26 de abril de 2002. Dispõe sobre a expansão da oferta de energia elétrica emergencial, recomposição tarifária extraordinária e cria o Programa de Incentivo às Fontes Alternativas de Energia Elétrica (Proinfa). Presidência da República, Casa Civil, Brasília, DF, 26 abr. 2002. $181^{\circ}$ da Independência e $114^{\circ}$ da República.

Burton T, Jenkins N, Sharpe D, Bossanyi E. 2011. Wind Energy Handbook. New York: John Wiley \& Sons.

Cancino-Solorzano Y, Xiberta-Bernat J. 2009. Statistical analysis of wind power in the region of Veracruz
(Mexico). Renewable Energy 34: 1628-1634. https:// doi.org/10.1016/j.renene.2008.11.018

Cresesb. 2001. Atlas do potencial eólico brasileiro. Available at http://www.cresesb.cepel.br/index.php?section $=$ publicacoes\&task=livro\& $\&$ cid $=1$; (accessed 2019 October 02)

Chandel SS, Ramasamy P, Murthy KSR. 2014. Wind power potential assessment of 12 locations in western Himalayan region of India. Renewable and Sustainable Energy Reviews 39: 530-545. https://doi. org/10.1016/j.rser.2014.07.050

Coelho CAS, Oliveira C, Ambrizzi T, Reboita MS, Carpenedo CB, Campos JLPS, Tomaziello ACN, Pampuch LA, Custódio MS, Dutra LMM, Rocha RP, Rehbein A. 2016. The 2014 southeast Brazil austral summer drought: regional scale mechanisms and teleconnections. Clim. Dynamics 46: 3737-3752. https://doi. org $/ 10.1007 / \mathrm{s} 00382-015-2800-1$

Cemig. 2019. $33^{\circ}$ Balanço Energético do Estado de Minas Gerais - BEEMG. Minas Gerais: CEMIG.

Cemig. 2010. Atlas Eólico de Minas Gerais. Minas Gerais: CEMIG.

Culture Change. 2017. The most frequently asked questions about wind energy (circa 2001-2004). Available at http://www.culturechange.org/wind.htm (accessed 2018 September 10)

Elliotti DL, Wendel LL, Gower GL. 1991. An assessment of the available wind energy potential in the contiguous United States. Springfield: Battelle.

Emeksiz C, Cetin T. 2019. In case study: Investigation of tower shadow disturbance and wind shear variations effects on energy production, wind speed and power characteristics. Sustainable Energy Technologies and Assessments 35: 148-159. https://doi.org/10.1016/j. seta.2019.07.004

EPE. 2019. Balanço Energético Nacional 2019: Ano Base 2018. São Paulo: EPE.

Hennessey Junior JP. 1977. Some Aspects of Wind Power Statistics. Journal of Applied Meteorology 16: 119128.

IBGE. 2018. Panorama. Available at https://cidades.ibge. gov.br/brasil/mg/panorama (accessed 2018 October 07)

INMET. 2018. Estações Automáticas. Available at http:// www.inmet.gov.br/portal/index .php? $r=$ estacoes/estacoesAutomaticas (accessed 2018 October 10)

IPCC, 2014: Climate Change 2014: Synthesis Report. Contribution of Working Groups I, II and III to the Fifth 
Assessment Report of the Intergovernmental Panel on Climate Change [Core Writing Team, R.K. Pachauri and L.A. Meyer (eds.)]. IPCC, Geneva, Switzerland, $151 \mathrm{pp}$.

Kalmikov A. 2017. Wind Power Fundamentals", Atmospheric and Planetary Sciences Massachusetts Institute of Technology. Available at https://www.researchgate. net/publication/317119352_Wind_Power_Fundamentals (accessed 2020 March 16)

Katinas V, Gecevicius G, Marciukaitis M. 2018. An investigation of wind power density distribution at location with low and high wind speeds using statistical model. Applied Energy 218: 442-451. https://doi. org/10.1016/j.apenergy.2018.02.163

Manwell JF, Mcgowan JG, Rogers AL. 2009. Wind Energy Explained: Theory, Design and Application. New York: John Wiley \& Sons.

NOAA. 2018. Global Forecast System (GFS) [0.5 Deg.]. Available at https://www.ncei.noaa. gov/access/metadata/landing-page/bin/iso?id=gov.noaa.ncdc:C00634 (accessed 2018 October 08)

Natividade UA, Garcia SR, Torres RR. 2017. Tendência dos Índices de Extremos Climáticos Observados e Projetado no Estado de Minas Gerais. Revista Brasileira de Meteorologia 32: 600-614. https://doi. org/10.1590/0102-7786324008

Patel MR. 2006. Wind and Solar Power Systems: Design, analysis and operation. New York: Taylor \& Francis Group.

Paula DLP, Cardoso FAC, Cardoso GPQ, Vieira EM. 2017. Modelagem espacial da velocidade do vento a 50, 75 e 100 metros de altura para o estado de Minas Gerais, Brasil, empregando geoestatística. Revista Brasileira de Geografia Física 10: 1281-1295. https:// doi.org/10.26848/rbgf.v10.4.p1281-1295

Pishgar-Komleh SH, Keyhani A, Sefeedpari P. 2015. Wind speed and power density analysis based on Weibull and Rayleigh distributions (a case study: Firouzkooh county of Iran). Renewable and Sustainable Energy Reviews 42: 313-322. https://doi.org/10.1016/j. rser.2014.10.028

Prasad VS, Johny CJ, Malo P, Singh SK, Rajagopal EN. 2017. Global retrospective analysis using NGFS for the period 2000-2011. Current Science 112-2: 370-377. https://www.jstor.org/stable/24912364

Prasad VS, Mohandas S, Gupta MD, Rajagopal EN, Dutta SK. 2011. Implementation of Upgraded Global Forecasting Systems (T382L64 and T574L64) at
NCMRW". Available at https://www.researchgate. net/publication/327727886_Implementation_of_Upgraded_Global_Forecasting_Systems_T382L64_and T574L64_at_NCMRWF (accessed 2020 March 14)

Raimundo DR, Santos IFS, Tiago Filho GL, Barros RM. 2018. Evaluation of greenhouse gas emissions avoided by wind generation in the Brazilian energetic matrix: A retroactive analysis and future potential. Resources, Conservation \& Recycling 137: 270-280. https://doi. org/10.1016/j.resconrec.2018.06.020

Rajagopal EN, Gupta MD, Mohandas S, Prasad VS, George JP, Iyengar GR, Kumar DP. 2007. Implementation of T254L64 Global Forecast System at NCMRWF. NCMRWF Technical Report: 1-42.

Ramos DNS, Lyra RFF, Silva Junior RSS, Cavalcante Segundo GH, Lopes GEV. 2018. Wind Power in Girau do Ponciano, Alagoas, Brazil Using Anemometric Data and Microscale Modeling. Revista Brasileira de Meteorologia 33: 279-288. https://doi.org/10.1590/01027786332007

Reboita MS, Amaro TR, Souza MR. 2018a. Winds: intensity and power density simulated by RegCM4 over South America in present and future climate. Climate Dynamics 51: 187-205. https://doi.org/10.1007/ s00382-017-3913-5

Reboita MR, Ambrizzi T, Silva BA, Pinheiro RF, Rocha RP. 2019. The South Atlantic Subtropical Anticyclone: Present and Future Climate. Frontiers in Earth Science 7: 1-15. https://doi.org/10.3389/feart.2019.00008

Reboita MS, Gan MA, Rocha RP, Ambrizzi T. 2010. Regimes de precipitação na América do Sul: Uma revisão bibliográfica. Revista Brasileira de Meteorologia 25: 185-204. http://dx.doi.org/10.1590/S010277862010000200004

Reboita MS, Marietto DMG, Souza A, Barbosa M. 2017. Caracterização atmosférica quando da ocorrência de eventos extremos de chuva na região sul de Minas Gerais. Revista Brasileira de Climatologia 21: 20-37. http://dx.doi.org/10.5380/abclima.v21i0.47577

Reboita MS, Marrafon VH, Llopart M, Rocha RP. 2018 b. Cenários de mudanças climáticas projetados para o estado de Minas Gerais. Revista Brasileira de Climatologia Ano 14: 110-128. http://dx.doi.org/10.5380/ abclima.v1i0.60524

Reboita MS, Rodrigues M, Silva LF, Alves MA. 2015. Aspectos climáticos do estado de Minas Gerais. Revista Brasileira de Climatologia 17: 206-226. http://dx.doi. org/10.5380/abclima.v17i0.41493 
Rego EE, Ribeiro CO. 2018. Successful Brazilian experience for promoting wind energy generation. The Electricity Journal 31: 13-17. https://doi.org/10.1016/j. tej.2018.02.003

Reis AL, Silva MS, Regis MV, Silveira WW, Souza AC, Reboita MS, Carvalho VSB. 2018. Climatologia e eventos extremos de precipitação no estado de Minas Gerais. Revista Brasileira de Geografia Física 11: 652660. https://doi.org/10.26848/rbgf.v11.2.p652-660

Ribeiro L. 2017. Mapa da crise hídrica bate recorde e já abrange 265 municípios de Minas Gerais. Available at https://www.em.com.br/app/noticia/gerais/2017/11/20/ interna_gerais, $917953 / \mathrm{mapa}$-da-crise-hidrica-baterecorde-e-ja-abrange-265-municipios-de-mg.shtml (accessed 2018 June 01)

Salviano MF, Groppo JD, Pellegrino GQ. 2016. Análise de Tendências em Dados de Precipitação e Temperatura no Brasil. Revista Brasileira de Meteorologia 31: 64-73. https://doi.org/10.1590/0102-778620150003

Shamshirband S, Keivani A, Mohammadi K, Lee M, Hamid SHA, Petkovic D. 2016. Assessing the proficiency of adaptive neuro-fuzzy system to estimate wind power density: Case study of Aligoodarz, Iran. Renewable and Sustainable Energy Reviews 59: 429-435. https://doi. org/10.1016/j.rser.2015.12.269

Shoaib M, Siddiqui I, Amir YM, Rehman SU. 2017. Evaluation of wind power potential in Baburband (Pakistan) using Weibull distribution function. Renewable and Sustainable Energy Reviews 70: 1343-1351. https:// doi.org/10.1016/j.rser.2016.12.037

Silva AR, Pimenta FM, Assireu AT, Spyrides MHC. 2016. Complementarity of Brazil's hydro and offshore wind power. Renewable and Sustainable Energy Reviews 56: 413-427. https://doi.org/10.1016/j.rser.2015.11.045

Silva ED, Reboita MS. 2013. Estudo da precipitação no estado de Minas Gerais - MG. Revista Brasileira de Climatologia 13: 120-136. http://dx.doi.org/10.5380/ abclima.v13i0.33345

Souza A, Bouzahir H, Tizgui I, Guezar F, Ozonur D. 2019. Probability distributions of Wind speed in the Campo Grande, MS, Brazil. Revista Brasileira de Climatologia 25: 138-160. http://dx.doi.org/10.5380/abclima. v25i0.64110

Tan C, Zhi Q. 2016. The Energy-Water Nexus: A literature Review of the Dependence of Energy on Water. Energy Procedia 88: 277-284. https://doi.org/10.1016/j. egypro.2016.06.154

The Wind Power. 2019. Wind Energy Market Intelligence: V90/2000. Available at https://www.thewindpower.net/ turbine_en_32_vestas_v90-2000.php (accessed 2019 December 02)

Wais P. 2017. A review of Weibull functions in wind sector. Renewable and Sustainable Energy Reviews 70: 1099-1107. https://doi.org/10.1016/j.rser.2016.12.014 


\section{Supplementary Material}

The intensity of the wind is characterized by two functions in the Weibull distribution, a density function and a cumulative one, which explain the probabilities of occurrence of certain velocity values by means of equations and coefficients, where one of the factors $k$ (shape) assumes values that explain the variability of the wind. Higher values of $k$ indicate greater constancy of winds, with less occurrence of extreme values. Statistical analysis was performed for each selected weather station. The data observed at the stations $(10 \mathrm{~m})$ and those simulated by the GFS data for the nearest grid points $(10$ and $100 \mathrm{~m})$ were considered. The calculation of the Weibull distribution was performed following the following stages:

1. Calculation of the standard deviation of speeds and average speed in each data set.

2. Calculation of the shape parameter $k$ from Equation 1, which is dimensionless.

3 . Using the average speeds and the $k$ values found, the values of the scale factor c were calculated in $\mathrm{ms}^{-1}$. The Gamma function $\Gamma$ has a certain complexity, which is why it was implemented using MATLAB ${ }^{\circledR}$ software.

4. Construction of frequency hydrographs, that is, the distribution of wind intensities over time and their respective probability densities (using the MATLAB ${ }^{\circ}$ software).

5. Adjustment of the Weibull curve following the shape and scale factors found. The graphics were made using the MATLAB ${ }^{\circledR}$ software.

The values of $c$ and $k$ for each meteorological station and for each data set are shown in Table IV and Figures 7 and 8. 